\title{
Palynoflora from the La Anita Formation (Maastrichtian), Austral-Magallanes Basin, Argentina
}

\author{
Patricio E. SANTAMARINA ${ }^{1}$, Viviana D. BARREDA ${ }^{1}$, Damián MOYANO PAZ², Camila \\ TETTAMANTI ${ }^{2}$, Ari IGLESIAS ${ }^{3}$, Daniel G. POIRÉ ${ }^{2} \&$ Augusto N. VARELA ${ }^{4,5}$
}

\begin{abstract}
${ }^{1}$ Museo Argentino de Cs. Ns. "B. Rivadavia”, CONICET, Av. Ángel Gallardo 470, Ciudad Autónoma de Buenos Aires (C1405DJR), Argentina. ${ }^{2}$ Centro de Investigaciones Geológicas, CONICET-UNLP, Diagonal $113 \mathrm{n}^{\circ} 275$, La Plata (B1904DPK), Buenos Aires, Argentina. ${ }^{3}$ Instituto de Investigaciones en Biodiversidad y Medioambiente,

CONICET-UNCO, Quintral 1250, San Carlos de Bariloche (8400), Rio Negro, Argentina. ${ }^{4}$ Cátedra de

Micromorfología de Suelos (Facultad de Ciencias Naturales y Museo - Universidad Nacional de La Plata), Calle 122 y 60 s/n (1900), La Plata, Argentina. ${ }^{5}$ Y-TEC S.A, Av. del Petróleo s/n (1923), Berisso, Argentina, and

Consejo Nacional de Investigaciones Científicas y Técnicas (CONICET), Argentina.

Email: santamarinape@gmail.com,vbarreda@macn.gov.ar,dmoyanopaz@cig.museo.unlp.edu.ar, ctettamanti@cig.museo.unlp.edu.ar,ari_iglesias@yahoo.com.ar, poire@cig.museo.unlp.edu.ar, augustovarela@cig.museo.unlp.edu.ar.
\end{abstract}

\begin{abstract}
Here we describe the spore and pollen assemblages recovered from the La Anita Formation, Late Cretaceous, Austral-Magallanes Basin $\left(\sim 50^{\circ} \mathrm{S}\right)$. This unit shows a high diversity of spores, with subordinate gymnosperms (mainly represented by Podocarpaceae) and angiosperms (mainly represented by Proteaceae and Arecaceae). The abundance of these groups varies between the two fertile studied levels, being one dominated by ferns (mainly Cyathidites minor and Laevigatosporites ovatus) and the other by gymnosperms (Podocarpidites spp.). The presence of aquatic ferns (Azollopsis), diverse Podocarpaceae and key angiosperm taxa (such as Arecipites, Clavatipollenites, Dichastopollenites, and Spinizonocolpites) is indicative of warm and hyper-humid conditions. The great abundance of Arecaceae and the presence of some key taxa (e.g. Azollopsis sp., Ericipites scabratus, Peninsulapollis gillii, Proteacidites spp.) support a probable Maastrichtian age for the uppermost strata of the La Anita Formation. The multivariate statistical analysis here conducted showed that the La Anita Formation has its greatest similarity with the La Irene Formation (Maastrichtian from the Austral-Magallanes Basin). Both formations are also related with other coeval palynofloras from Patagonia and Antarctica.
\end{abstract}

Key words: Late Cretaceous, Austral-Magallanes Basin, Patagonia, palynology.

Resumen: Palinoflora de la Formación La Anita (Mastrichtiano), Cuenca Austral-Magallanes, Argentina. Se describen aquí la asociaciones palinológicas recuperadas de la Formación La Anita, Cretácico tardío, Cuenca Austral-Magallanes $\left(\sim 50^{\circ} \mathrm{S}\right)$. La unidad muestra una alta diversidad de esporas, con gimnospermas (principalmente representadas por Podocarpaceae) y angiospermas (principalmente representadas por Proteaceae y Arecaceae) subordinadas. La abundancia de estos grupos varía entre los dos niveles fértiles estudiados, siendo uno dominado por helechos (principalmente Cyathidites minor y Laevigatosporites ovatus) y otro por gimnospermas (Podocarpidites spp.). La presencia de helechos acuáticos (Azollopsis), diversas podocarpáceas y angiospermas megatérmicas (como Arecipites, Clavatipollenites, Dichastopollenites, y Spinizonocolpites) es indicativa de condiciones cálidas e híper húmedas. La gran abundancia de Arecaceae y la presencia de algunos taxones diagnósticos temporalmente (e.g. Azollopsis sp., Ericipites scabratus, Peninsulapollis gillii, Proteacidites spp.) apoyan una probable edad Maastrichtiana para los niveles cuspidales de la Formación La Anita. El análisis estadístico multivariado mostró que la Formación La Anita posee sus mayores similitudes con la Formación La Irene (Maastrichtiano de la Cuenca Austral-Magallanes). Ambas formaciones se encuentran también relacionadas con otras palinofloras coetáneas de Patagonia y Antártida.

Palabras clave: Cretácico Superior, Cuenca Austral-Magallanes, Patagonia, palinología. 


\section{INTRODUCTION}

The Late Cretaceous is a critical interval to understand the evolution of floras around the world, a time when angiosperms became dominant components in terrestrial ecosystems for the first time (Friis et al., 2011; Lupia et al., 1999; Nagalingun et al., 2002; Barreda et al., 2019), and a number of new lineages have their origin, such as Proteaceae and Nothofagaceae in the high southern latitudes (e.g. Dettmann \& Thomson, 1987, Askin, 1990b; Cantrill \& Poole, 2005). In southern South America terrestrial palynological records are sparse (Papú, 1988a, b, 1989; Baldoni, 1992; Baldoni \& Askin, 1993; Papú, 2002; Povilauskas et al., 2008; Povilauskas, 2010, 2011, 2012, 2013, 2016; Vallati, 2010; Novas et $a l ., 2019)$, with several geologic units with no information on their spore-pollen content. For this reason, the study of new assemblages is essential for evaluating the evolution of austral floras and will also serve as a basis to better evaluate the magnitude of the drop in plant diversity and abundance throughout the $\mathrm{K} / \mathrm{Pg}$ boundary (Barreda et al., 2012).

The purpose of this paper is to describe the palynological assemblages recovered from the La Anita Formation (Bianchi, 1967), AustralMagallanes Basin, Southern Patagonia; to refine the age and the paleoclimatic conditions that prevailed during the deposition of this unit; and, to integrate and compare this results with what is known of Late Cretaceous palynofloras of Patagonia (La Irene, Lefipán, Loncoche, Monte Chico, Cerro Cazador, Allen and Paso del Sapo formations) and Antarctica (Lopez de Bertodano Formation) using statistical methods.

This is the first work in a series that aim to study and update the palynological fossil record from the Late Cretaceous in Patagonia in order to better understand the evolution of southern South American floras.

\section{GEOLOGICAL SETTING AND STUDIED SECTION}

The La Anita Formation is part of a prograding siliciclastic wedge accumulated during the foreland stage of the Austral-Magallanes Basin (Santa Cruz Province, southern Argentina). It covers the deep-marine Alta Vista Formation, and is covered by continental deposits of the Cerro Fortaleza and La Irene formations (Macellari et al., 1989; Moyano Paz et al., 2018; Tettamanti et $a l ., 2018)$. The La Anita Formation is character- ized by sandstones and pebbly sandstones, with subordinate mudstones and heterolithic deposits (Moyano Paz et al., 2018). It was assigned to the Campanian based on both ammonites (Riccardi \& Rolleri, 1980, Riccardi, 1983; Kraemer \& Riccardi, 1997) and detrital zircons (Sickmann et al., 2018; 2019).

The La Anita Formation was interpreted as a delta system with vertical variation on the relative roles of processes affecting it; thus, a wavedominated lower unit and a fluvio-dominated upper unit were defined by Moyano Paz et al. (2018). Both units are separated by a regional erosion surface related to a relative sea level fall. The wave-dominated lower unit grades from the deep-marine fine-grained sediments of the Alta Vista Formation, into a dominantly sandy, graycolored succession. The presence of trace fossils suites and the abundance of wave-generated structures, indicate high-energy conditions, associated with a high recurrence of storm events. However, the low abundance and diversity of these traces could be related to a stressing condition produced by low salinity and bottom oxygenation due to fluvial-discharge effects. The fluvio-dominated upper unit shows a general coarser grain size. It is composed by high-sinuosity, multi-story distributary channels, along with fine-grained deposits related to interdistributary areas, with no evidence of wave nor tidal influence. The upper unit shows evidence of deposition in a brackish-water environment, such as the presence of a trace suite attributable to a stressed expression of the Skolithos ichnofacies.

The studied section crops out $4 \mathrm{~km}$ south of Calafate City, Santa Cruz province; at the base of Calafate Hill, in a fresh cliff in the Calafate Creek (50²2'15.67'S 72¹4'12.30”W; Fig. 1). This locality represents the uppermost facies of the upper unit of the La Anita Formation, and is characterized by fine- to medium-grained yellowish sandstone bodies with trough-cross stratification, tabular fine dark laminated organic-rich claystones, and channelized sandstone bodies with trough-cross stratification and abundant carbonaceous material (Fig. 2). Fossil leaf compressions of conifers and ferns were found; as well as leaves, fruits and seeds of angiosperms.

\section{MATERIALS AND METHODS}

Two levels from the La Anita Formation were productive for palynology: CCC-A from a coal level (collection number MPM-Pb-18963) and CCC-B from a siltstone level (collection number 


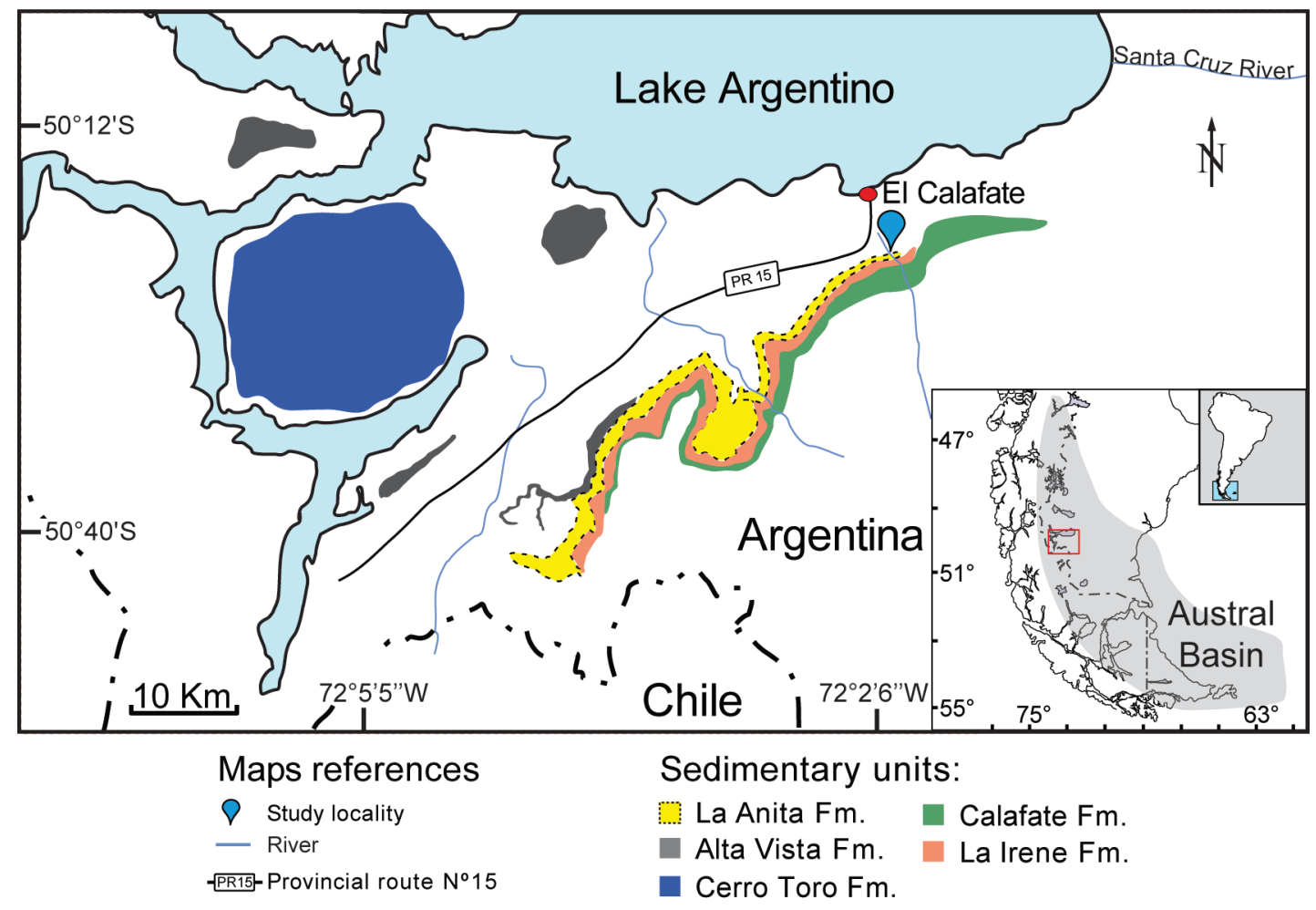

Fig. 1. Geological map of the studied area.

MPM-Pb-18964), both within interdistributary areas on a delta plain fine grained deposits (Fig. 2). Samples were processed following standard palynological techniques, and mounted in a glycerol mounting medium. The observations were made under a Leica DM2500 light microscope and the photographs were taken with a Leica DFC295 digital camera. Specimen locations refer to England Finder coordinates. In order to obtain the relative abundance of plant groups, counts of at least 300 individuals were conducted. Broken individuals were not counted, and tetrads and polyads were counted as one individual. The specimens are stored at the paleobotanical collection of the Museo Regional Provincial "Padre Jesús Molina", Rio Gallegos, Santa Cruz Province (acronym MPM-Pb).

A presence/absence matrix was constructed (see Appendix) in order to compare the sporepollen assemblages of the La Anita Formation with coeval palynofloras from the La Irene (Povilauskas et al., 2008), Lefipán (Baldoni, 1992; Baldoni \& Askin, 1993; Barreda et al., 2012), Loncoche (Papú, 2002), Paso del Sapo (Papú, 1988a, b, 1989), Allen (Vallati, 2010), Monte Chico and Cerro Cazador (Povilauskas, 2010, 2011,
2012, 2013, 2016) formations from Argentina and the López de Bertodano Formation from the Antarctic Peninsula (Baldoni \& Barreda, 1986; Dettmann \& Thomson, 1987; Askin, 1990a, b, 1994; Dolding, 1992; Bowman et al., 2014). A cluster analysis was conducted using the program PAST version 3.1 (Hammer et al., 2001). The unweighted pair-group method (UPGMA) was chosen for constructing the dendrogram, and Jaccard Similarity Index was applied to measure similarities between palynofloras.

\section{RESULTS}

The recovered assemblages from the La Anita Formation at the Cerro Calafate locality are very well preserved and integrated by spores, pollen grains, plant tissue fragments and fungal remains. A total of 42 spores and pollen species were identified, representing 3 bryophytes, 14 ferns, 11 gymnosperms, 13 angiosperms and 1 fresh-water algae (Table 1).

The spore-pollen assemblage recovered from sample CCC-A is dominated by ferns $(93.9 \%$, mainly represented by Cyathidites minor and Laevigatosporites ovatus), followed by gymno- 


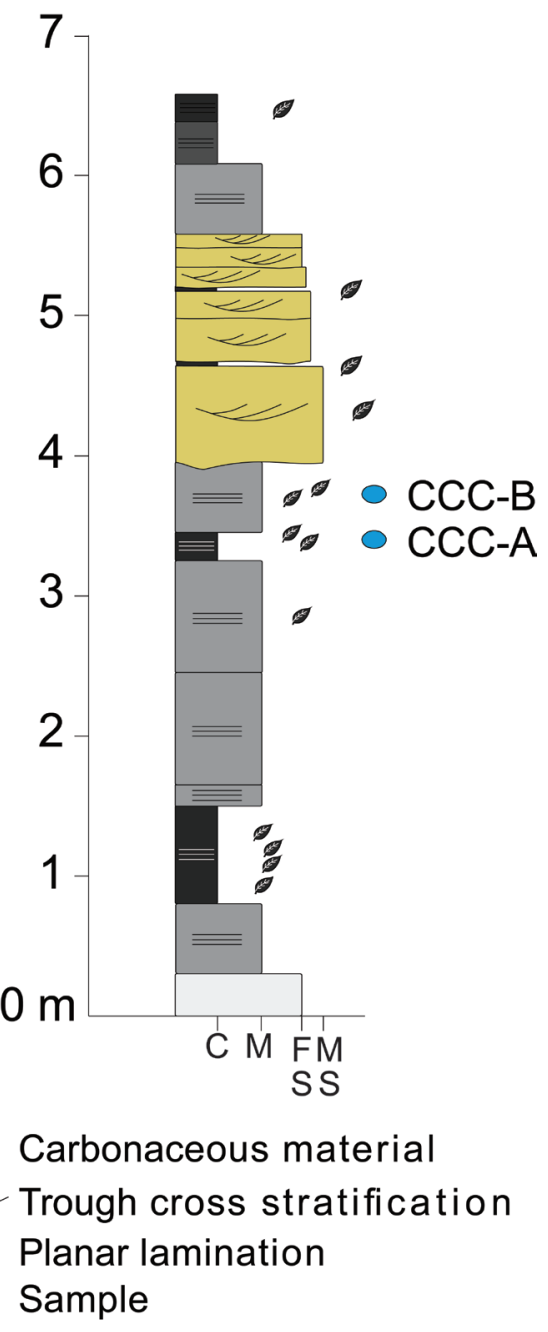

Fig. 2. Sedimentological section studied.

sperms $(4.2 \%)$ and angiosperms (1.4\%) (Table 2). Zygnemataceae zygospores, Classopollis spp., Ericipites scabratus, Liliacidites kaitangataensis, Peninsulapollis gillii, Spinizonocolpites hialinus and Tricolpites reticulatus are exclusive from this level (Figs. 3, 4).

The assemblage recovered from sample CCC-B is dominated by gymnosperms $(69.2 \%)$, followed by ferns (17.9\%) and angiosperms (12.8\%) (Table 2). The most important groups in this assemblage are: Podocarpaceae (67.6\%), represented mainly by the genus Podocarpidites, and Arecaceae (11.5\%), represented by Arecipites minutiscabratus. Podocarpidites marwickii, $P$. rugulosus, Podocarpidites sp., ?Rhoipites sp., Lewalanipollenites sp., Proteacidites spp. and Dichastopollenites sp., are exclusive from this level (Figs. 3, 4).
Based on a presence/absence matrix of taxa, a cluster analysis was conducted, resulting in the dendrogram illustrated in Figure 5. Similarities between formations are generally low. A main group can be identified, composed by the La Anita, La Irene, Monte Chico, Cerro Cazador (Maastrichtian-Danian from Austral-Magallanes Basin), Loncoche (Maastrichtian from Neuquén Basin) and Lefipán (Maastrichtian-Danian from the Cañadón Asfalto Basin) formations. It can be divided in two subgroups: Subgroup A composed by the La Anita and La Irene formations, and Subgroup B composed by the Monte Chico, Cerro Cazador, Loncoche and Lefipán formations.

The lowest similarity values are hold by the Lopez de Bertodano (Maastrichtian-Danian from Antarctic Peninsula) and Paso del Sapo (Campanian-Maastrichtian from the Cañadón Asfalto Basin) formations.

\section{DISCUSSION AND CONCLUSIONS}

The palynoflora recovered from the upper unit of the La Anita Formation suggests two different plant communities. Sample CCC-A has a high relative abundance of Cyathidites minor (both monads and polyads), with Matonisporites equiexinus, Spinizonocolpites hialinus and Zygnemataceae zygospores. The fern family Matoniaceae lives in the tropical regions of southeastern Asia (Tryon \& Lugardon, 1990). S. hialinus is related to Arecaceae (Archangelsky, 1973; Martinez et al., 2016) an angiosperm tropical family with low resistance to frosts (Heywood et al., 2007). The Zygnemataceae produce zygospores in clean, oxygen-rich, stagnant, shallow fresh water bodies, where the temperature can rise quickly to the level required for this process (van Geel, 1976). This association suggests a vegetation developed near a lake or a coastal marsh, under hiper-humid and warm conditions.

Sample CCC-B represents an inland forest, dominated by Podocarpaceae (Podocarpidites spp.) and Arecaceae (Arecipites minutiscabratus), with a minor presence of Proteaceae (Lewalanipollis sp., Peninsulapollis sp., and Proteacidites sp.).

Most of the spore and pollen species recovered from the La Anita Formation are long-ranging and can only give a general idea about the age of the upper levels of the La Anita Formation. The great abundance of Arecaceae at high and middle latitudes in the southern hemisphere is achieved towards the end of the Cretaceous (Barreda et al., 2012). Also, S. hialinus was recorded in 
A

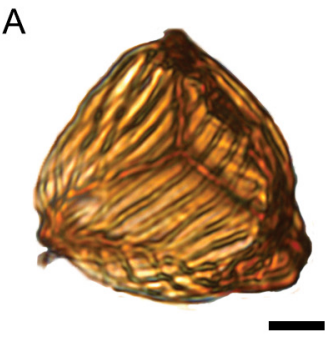

E
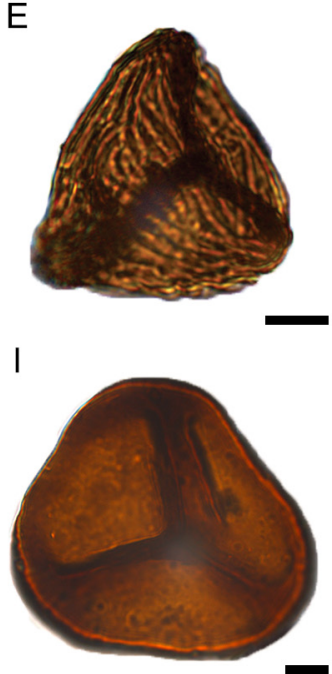

M

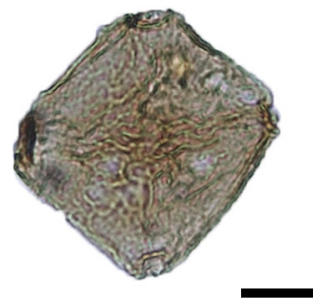

Q

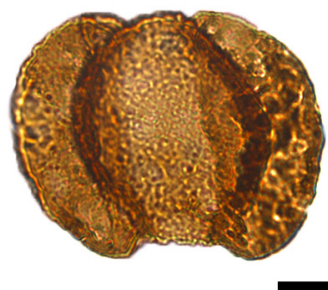

B

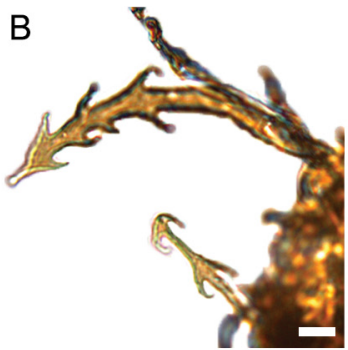

$\mathrm{F}$

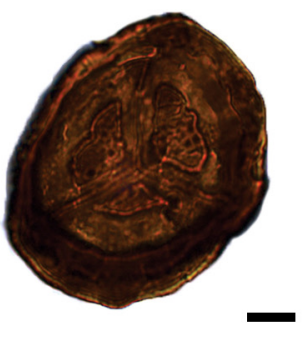

$J$

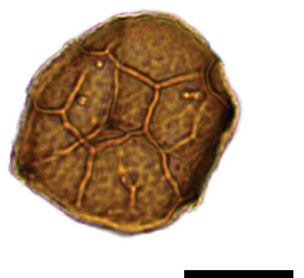

$\mathrm{N}$

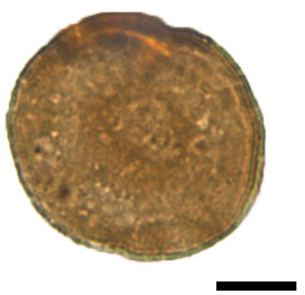

$\mathrm{R}$

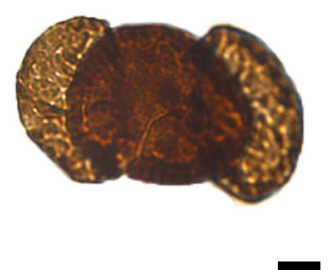

C

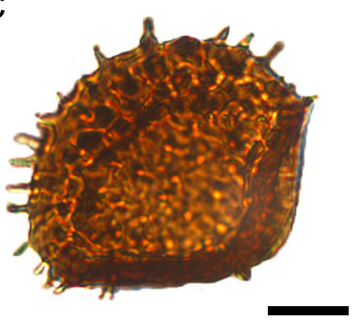

G

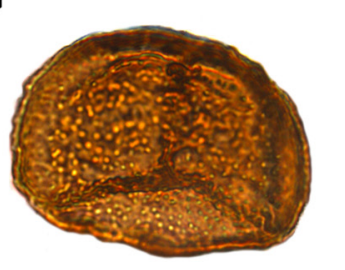

K

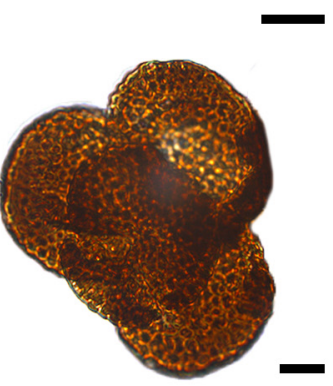

$\mathrm{O}$

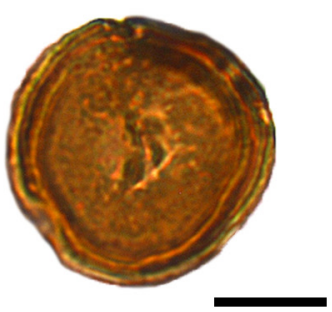

$S$

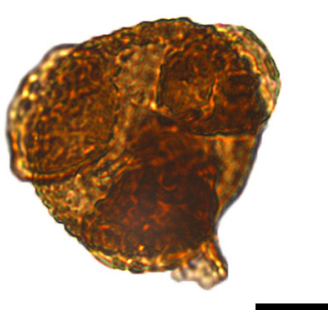

D

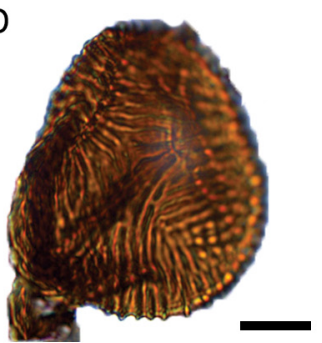

$\mathrm{H}$

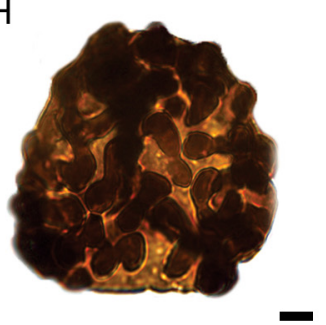

$\mathrm{L}$

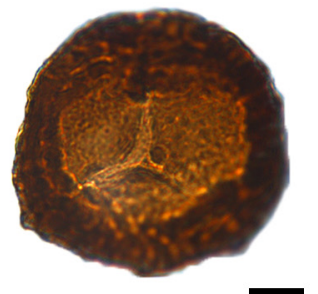

$P$

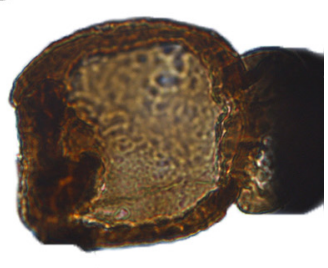

$\mathrm{T}$

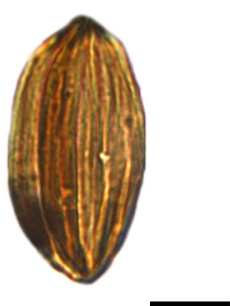

Fig. 3. Spores and gymnosperms. A. Appendicisporites sp. (MPM-Pb-18964 d: E57/4). B. Azollopsis sp. (MPM-Pb18963 b: G56). C. Ceratosporites equalis (MPM-Pb-18964 f: E54). D. Cicatricosisporites cf. minutaestriatus (MPM$\mathrm{Pb}-18964$ b: F50). E. Cicatricosisporites hallei (MPM-Pb-18964 f: G38). F. Cyatheacidites annulatus (MPM-Pb18964 a: E41/3). G. Foraminisporis assymetricus (MPM-Pb-18963 a: O41/2). H. Interulobites sp. (MPM-Pb-18964 a: T32/3). I. Matonisporites equiexinus (MPM-Pb-18963 b: P45). J. Triporoletes reticulatus (MPM-Pb-18963 b: H45/1). K. Rugulatisporites sp. tetrad (MPM-Pb-18963 a: J56); L. Rugulatisporites sp. (MPM-Pb-18963 a: Q55/2); M. Zygnemataceae zygospore (MPM-Pb-18963 d: C32/2). N. Classopollis sp. 1 (MPM-Pb-18963 c: T45). O. Classopollis sp. 2 (MPM-Pb-18963 e: O39). P. Phyllocladidites mawsonii (MPM-Pb-18963 a: D40/3). Q. Podocarpidites cf. ellipticus (MPM-Pb-18963 b: E50). R. Podocarpites rugulosus (MPM-Pb-18964 b: D40/3). S. Microcachryidites antarcticus (MPM-Pb-18963 c: L36/4). T. Ephedripites notensis (MPM-Pb-18964 g: S38/2). Scale bar: $10 \mu \mathrm{m}$. 
A

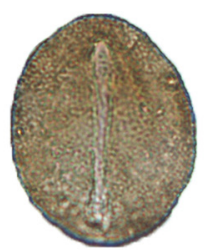

E

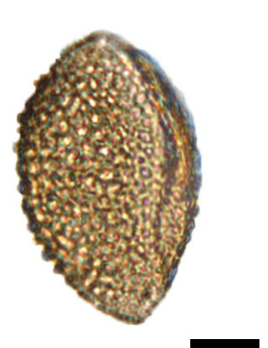

I

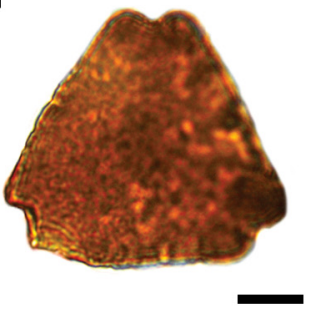

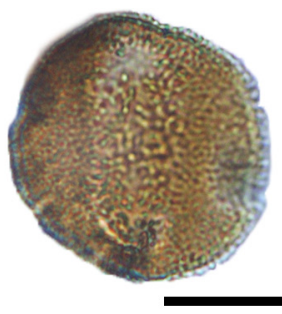

$\mathrm{F}$

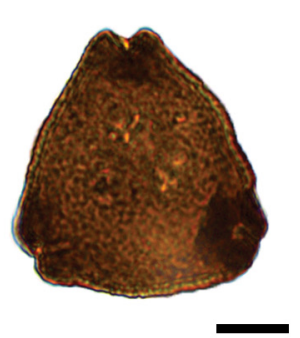

$\mathrm{J}$

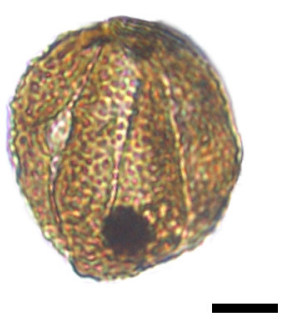

C

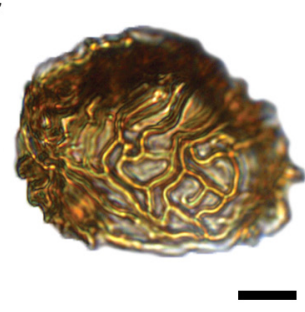

G

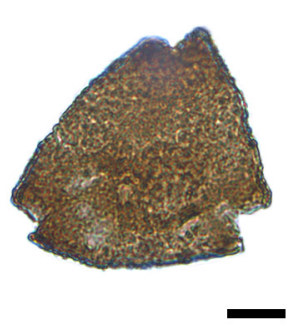

$\mathrm{K}$

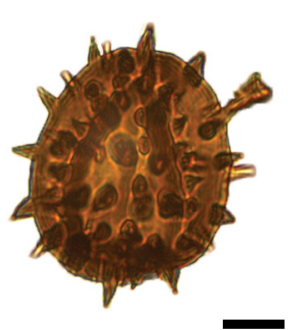

D

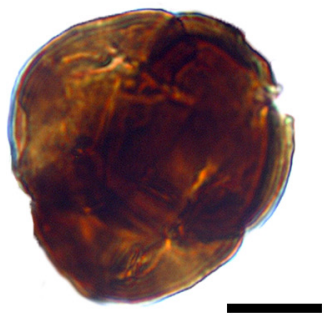

$\mathrm{H}$

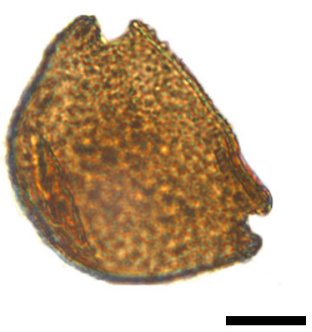

$\mathrm{L}$

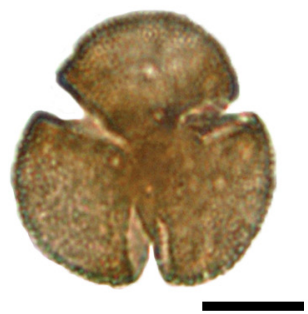

Fig. 4. Angiosperms. A. Arecipítes minutiscabratus (MPM-Pb-18963 c (P2): U52). B. Clavatipollenites hughesii (MPM-Pb-18964 d, F50). C. Dichastopollenites sp. (MPM-Pb-18964 d: C53). D. Ericipites scabratus (MPMPb-18963 e: Q57). E. Liliacidites kaitangataensis (MPM-Pb-18963 c: V41/2). F. Lewalanipollis sp. (MPM-Pb18964 f: G37). G. Peninsulapollis sp. (MPM-Pb-18964 e: S45). H. Proteacidites sp. 1 (MPM-Pb-18964 d: T59). I. Proteacidites sp. 2 (MPM-Pb-18964 d: C48). J. ?Rohipites sp. (MPM-Pb-18964 d: L60/2). K. Spinizonocolpites hialinus (MPM-Pb-18963 c: N35/4). L. Tricolpites reticulatus (MPM-Pb-18964 g: C41/3). Scale bar: $10 \mu \mathrm{m}$.

the Loncoche and Lefipán formations, from the Campanian-Maastrichtian of Patagonia (Baldoni \& Askin, 1993; Papu, 2002; Barreda et al., 2012). The oldest palynological record of Proteaceae in the Antarctic Peninsula occurs at the middle Santonian, extending to southern South America at the Campanian-Maastrichtian (Askin \& Baldoni, 1998). In Argentina, Peninsulapollis gillii was first recorded from the Los Alamitos Formation of Campanian age (Papú \& Sepúlveda, 1995), meanwhile Proteacidites was described in multiple Maastrichtian and Danian sequences (Baldoni \& Askin, 1993; Povilauskas, 2010, 2013; Volkheimer et al., 2007). The oldest records of Ericipites scabratus in Patagonia are from the Maastrichtian on both the Lefipán (Baldoni \& Askin, 1993) and La Irene (Povilauskas et al., 2008) formations. These records suggest a Late Cretaceous, probably Maastrichtian age for the upper sections of the La Anita Formation. Also, in the studied area, the La Anita Formation is unconformably covered by the Maastrichtian La Irene Formation, restricting its maximum age (Povilauskas et al., 2008).

Based on the cluster analysis, the La Anita Formation shows its greatest similarities with La Irene Formation. These units share 15 species: C. equalis, C. minor, G. senonicus, L. ovatus, T. reticulatus, $R$. austroclavatidtes, $M$. antarcticus, P. elegans, P. ellipticus, A. minutiscabratus, $E$. scabratus, P. gillii, Proteacidites sp., Rhoipites sp., and S. hialinus. The locality of the La Irene Formation studied by Povilauskas et al. (2008) is close both, geographically and stratigraphically, from the one presented here. Both formations share similarities on its inferred floral assemblage (a plant community dominated by ferns and angiosperms, with absence of Nothofagaceae) as well as its depositional conditions (a fluvio-dominated delta environment developed under warm and humid climatic conditions). The two abundance histograms pre- 
Table 1. List of taxa.

\begin{tabular}{|c|c|c|c|}
\hline \multirow[t]{2}{*}{ Morphogenus } & \multirow[t]{2}{*}{ Affinity } & \multicolumn{2}{|c|}{ Sample } \\
\hline & & CCC-A & CCC-B \\
\hline Appendicisporites sp. Weyland \& Krieger, 1953 & Anemiaceae & & $\mathrm{X}$ \\
\hline Azollopsis sp. & Azollaceae & $\mathrm{X}$ & \\
\hline Biretisporites crassilabratus Archangelsky,1972 & Hymenophyllaceae & $\mathrm{X}$ & $\mathrm{X}$ \\
\hline Ceratosporites equalis Cookson \& Dettmann, 1958 & Selaginellaceae/Lycopodiaceae & $\mathrm{X}$ & \\
\hline Cicatricosisporites cf. minutaestriatus Pocock, 1964 & Anemiaceae & $\mathrm{X}$ & $\mathrm{x}$ \\
\hline Cicatricosisporites hallei Delcourt \& Sprumont, 1955 & Anemiaceae & & $\mathrm{x}$ \\
\hline Cyathidites minor Couper, 1953 & Filicopsida & $\mathrm{x}$ & $\mathrm{x}$ \\
\hline Cyatheacidites annulatus Cookson, 1947 & Lophosoriaceae & & $\mathrm{x}$ \\
\hline Densoisporites velatus Weyland \& Krieger, 1953 & Selaginellaceae & $\mathrm{X}$ & \\
\hline Foraminisporis assymetricus Dettmann, 1963 & Bryophyta & $\mathrm{X}$ & \\
\hline Gleicheniidites senonicus Ross, 1949 & Gleicheniaceae (G. circinata) & & $\mathrm{X}$ \\
\hline Interulobites sp. & ¿Bryophyta & & $\mathrm{x}$ \\
\hline Laevigatosporites ovatus Wilson \& Webster, 1946 & Filicopsida & $\mathrm{X}$ & $\mathrm{x}$ \\
\hline Retitriles austroclavatidites Cookson, 1953 & Lycopodiaceae (Lycopodium) & $\mathrm{x}$ & \\
\hline Matonisporites equiexinus Couper, 1958 & Matoniaceae & $\mathrm{x}$ & \\
\hline Rugulatisporites sp. & Osmundaceae & $\mathrm{x}$ & $\mathrm{x}$ \\
\hline Triporoletes reticulatus (Pocock) Playford, 1971 & Bryophyta (Riccia) & $\mathrm{x}$ & \\
\hline Zygospores indet. & Zygnemataceae & $\mathrm{x}$ & \\
\hline Araucariacites australis Cookson, 1947 & Araucariaceae & $\mathrm{X}$ & $\mathrm{x}$ \\
\hline Classopollis sp. 1 & Cheirolepidiaceae & $\mathrm{x}$ & \\
\hline Classopollis sp. 2 & Cheirolepidiaceae & $\mathrm{X}$ & \\
\hline Ephedripites notensis Cookson, 1957 & Ephedraceae & $\mathrm{X}$ & $\mathrm{x}$ \\
\hline Microcachryidites antarcticus Cookson, 1947 & Podocarpaceae & $\mathrm{x}$ & $\mathrm{X}$ \\
\hline Phyllocladidites mawsonii Cookson, 1947 & Podocarpaceae & $\mathrm{x}$ & \\
\hline Podocarpidites cf. ellipticus Cookson, 1947 & Podocarpaceae & $\mathrm{x}$ & $\mathrm{X}$ \\
\hline Podocarpidites marwickii Couper, 1953 & Podocarpaceae & & $\mathrm{X}$ \\
\hline Podocarpidites rugulosus Romero, 1977 & Podocarpaceae & & $\mathrm{X}$ \\
\hline Arecipites minutiscabratus (McIntyre) Milne, 1988 & Arecaceae & $\mathrm{x}$ & $\mathrm{x}$ \\
\hline Clavatipollenites hughesii Couper, 1958 & Chlorantaceae & & $\mathrm{X}$ \\
\hline Dichastopollenites sp. & ?Nymphaeaceae (Nymphaea) & & $\mathrm{x}$ \\
\hline Ericipites scabratus Harris, 1965 & Ericales & $\mathrm{X}$ & \\
\hline Lewalanipollis sp. & Proteaceae & & $\mathrm{x}$ \\
\hline Liliacidites kaitangataensis Couper, 1953 & Liliaceae/Iridaceae & $\mathrm{x}$ & \\
\hline Peninsulapollis gillii Dettmann \& Jarzen, 1988 & Proteaceae (Beauprea) & $\mathrm{x}$ & \\
\hline Peninsulapollis sp. & Proteaceae (Beauprea) & & $\mathrm{X}$ \\
\hline Proteacidites sp. 1 & Proteaceae & & $\mathrm{x}$ \\
\hline Proteacidites sp. 2 & Proteaceae & & $\mathrm{x}$ \\
\hline ?Rhoipites sp. & Angiosperma incertae sedis. & & $\mathrm{x}$ \\
\hline Spinizonocolpites hialinus Archangelsky \& Zamaloa, 1986 & Arecaceae & $\mathrm{x}$ & \\
\hline Tricolpites reticulatus Cookson, 1947 & Gunneraceae (Gunnera) & $\mathrm{x}$ & \\
\hline
\end{tabular}

sented by Povilauskas et al. (2008) are also similar with the counts presented here. One level is strongly dominated by trilete psilate spores, with low representation of gymnosperm and angiosperm pollen grains; and the second level shows lesser abundance of spores and an increase in angiosperm pollen grains (mainly Arecaceae and Chloranthaceae). However, the La Anita Formation presents a much greater abundance of Podocarpaceae (67\% in CCC-B) than the La Irene 
Table 2. Counts expressed in absolute frequencies and percentages.

\begin{tabular}{|c|c|c|c|c|}
\hline \multirow[t]{3}{*}{ Taxonomic group } & \multicolumn{4}{|c|}{ Sample } \\
\hline & \multicolumn{2}{|c|}{ CCC-A } & \multicolumn{2}{|c|}{ CCC-B } \\
\hline & $\mathrm{n}^{\circ}$ & $\%$ & $\mathrm{n}^{\circ}$ & $\%$ \\
\hline Anemiaceae & 3 & 0.8 & 3 & 0.96 \\
\hline Filicopsida & 322 & 91.7 & 45 & 14.42 \\
\hline Matoniaceae & 5 & 1.4 & - & - \\
\hline Gleicheniaceae & - & - & 3 & 0.96 \\
\hline Osmundaceae & - & - & 2 & 0.64 \\
\hline Schyzaceae & - & - & 3 & 0.96 \\
\hline Araucariaceae & 10 & 2.8 & 5 & 1.6 \\
\hline Podocarpaceae & 5 & 1.4 & 211 & 67.62 \\
\hline Arecaceae & 5 & 1.4 & 36 & 11.53 \\
\hline Chlorantaceae & - & - & 2 & 0.64 \\
\hline Proteaceae & - & - & 2 & 0.64 \\
\hline Zygnemataceae & 1 & 0.3 & - & - \\
\hline Total & 351 & 100 & 312 & 100 \\
\hline
\end{tabular}

Formation (4-10\% in Povilauskas et al., 2008).

The palynofloras from the Cerro Cazador and

Monte Chico formations, show great similarities with those from the coeval Loncoche, Lefipán and La Irene formations (Povilauskas 2010, 2011, 2012, 2013, 2016). These Patagonian palynofloras share general characteristics, such as: great diversity and abundance of spores, presence of Arecaceae (Arecipites) and Liliaceae (Liliacidites), and low representation of Podocarpaceae. The palynoflora here studied also present these characteristics; but has a greater representation of Podocarpaceae.

The assemblages from the Lopez de Bertodano Formation (Antarctic Peninsula), represent a completely different floral setting: a podocapaceous/Nothofagidites dominated rainforest, with great diversity of Nothofagaceae, Proteaceae and Myrtaceae (Dettmann \& Thompson, 1987; Bowman et al., 2014). These palynological assemblages show a mixed of cool temperate palynomorphs (such as Nothofagidites and Phyllocladidites) along with warmer climate indicators (particularly in the late Maastrichtian, such as Peninsulapollis, Bombacacidites and Anacolosidites). The vegetation in the Antarctic Peninsula was probably zoned by altitude, with the megathermic plant associations occupying

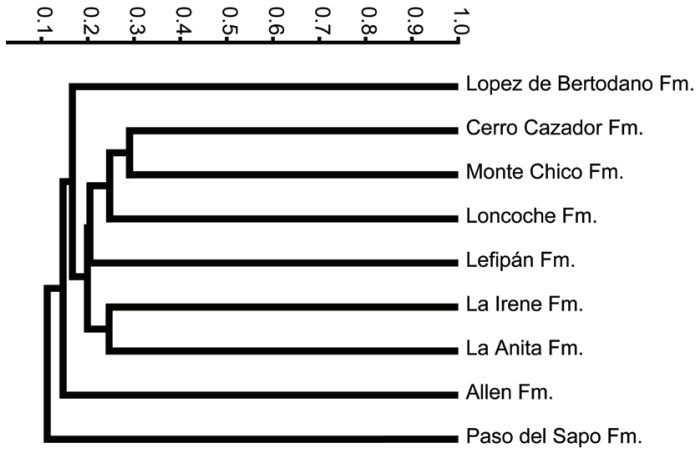

Fig. 5. Dendrogram derived from the cluster analysis.

coastal/lowland areas and cool climate associations in the higher altitude, inland areas (Askin, 1990b). These characteristics separate the palynofloras of the Antarctic Peninsula, from those of Patagonia, resulting in low similarity values among them.

The assemblage from the Allen Formation (Maastrichtian of the Neuquen Basin) have species characteristics from both, southern (Cicatricosisporites, Lewalanipollis, Penninsulapollis, Podocarpidites, and Proteacidites) and paleoequatorial latitudes (Gabonisporis and Tricesticillus). Interestingly, this scenario is somehow comparable to that previously reported for the Early Cretaceous of central Argentina, where a "Transition Zone" was defined (Pramparo, 1990). This unit only shows gross similarities with the La Anita Formation

Previous cluster analysis of CampanianMaastrichtian palynofloras from Patagonia (Povilauskas et al., 2008; Povilauskas, 2016), found great similarities between the Paso del Sapo Formation and other Patagonian palynofloras. However, our analysis shows only gross similarities among them; the observed differences are related to the fact that, in our analysis, we considered all the species recorded in the Paso del Sapo Formation (not only those share with the La Anita Formation) which highlights the high level of endemism of the Paso del Sapo Formation assemblages, with the exclusive presence of Conbaculatisporites sp., Cycadopites follicularis, Cycadopites punctatus, Entylissa sp., Klulcisporites pachydictyus, Laevigatosporiles gracilis, Laevigatosporites vulgaris, Marallisporites scabratus, Momipites fragilis, Podocarpidites verrucosus, and Waltzispora sp. among the most significant.

The new palynological records of the La Anita Formation widen our knowledge of the latest Late Cretaceous floras in southern Patagonia. 
The similarities detected by our cluster analysis helps to refine the composition and geographic distribution of the Late Cretaceous austral vegetation previous to the floral turnover of the Cretaceous-Paleogene boundary.

\section{ACKNOWLEDGMENTS}

The authors would like to thank the Secretaría de Cultura de la Provincia de Santa Cruz and the Comisión de Fomento from Tres Lagos Town. To O. Cardenas for processing the palynological materials and L. Villar de Seoane, M. Luengo and S. Richiano for their comments. We are grateful to V. Perez-Loinaze and M. Quattrocchio for their critical comments as reviewers of the manuscript. This research was funded by the Consejo Nacional de Investigaciones Científicas y Técnicas (PIP 1016/10 and PIP 2014-0259) and by the Agencia Nacional de Promoción Científica y Tecnológica (PICT 2012-0828, PICT 20130388, and PICT 2017-0671).

Appendix. Supplementary data to this article can be found online at revista.macn.gob.ar/ojs/index. $\mathrm{php} /$ RevMus/rt/suppFiles/664/0

\section{BIBLIOGRAPHY}

Archangelsky, S. 1973. Palinología del Paleoceno de Chubut. 1. Descripciones sistemáticas. Ameghiniana 10(4): 339-399.

Askin, R.A. 1990a. Cryptogam spores from the upper Campanian and Maastrichtian of Seymour Island, Antarctica. Micropaleontology 36(2): 141-156.

Askin, R.A. 1990b. Campanian to Paleocene spore and pollen assemblages of Seymour Island, Antarctica. Review of Palaeobotany and Palynology 65(1-4): 105-113.

Askin, R.A. 1994. Monosulcate angiosperm pollen from the López de Bertodano Formation (upper Campanian-Maastrichtian-Danian) of Seymour island, Antarctica. Review of Palaeobotany and Palynology 81(2-4): 151-164.

Askin, R.A. \& A.M. Baldoni. 1998. The Santonian through Paleogene record of Proteaceae in the southern South America-Antarctic Peninsula region. Australian Systematic Botany 11: 373-390.

Baldoni, A.M. 1992. Palynology of the lower Lefipan Formation (Upper Cretaceous) of Barranca de Los Perros, Chubut Province, Argentina. Part I. Cryptogam spores and gymnosperm pollen. Palynology 16(1): 117-136.

Baldoni, A.M. \& R.A. Askin. 1993. Palynology of the lower Lefipan Formation (Upper Cretaceous) of Barranca de los Perros, Chubut Province, Argentina, Part II. Angiosperm pollen and discussion. Palynology 17: 241-264.
Baldoni, A.M. \& V.D. Barreda. 1986. Estudio palinológico de las formaciones López de Bertodano y sobral, Isla Vicecomodoro Marambio, Antártida. Boletim IG-USP. Série Científica 17: 89-96.

Barreda V.D., N.R. Cúneo, P. Wilf, E.D. Currano, R.A. Scasso, et al. 2012. Cretaceous/Paleogene Floral Turnover in Patagonia: Drop in diversity, low extinction, and a Classopollis spike. PLoS ONE 7(12): e52455.

Barreda, V.D., L. Palazzesi \& E.B. Olivero. 2019. When flowering plants ruled Antarctica: evidence from Cretaceous pollen grains. New Phytologist 223(2): 1023-1030.

Bianchi, J.L. 1967. Informe preliminar acerca de los perfiles estratigráficos realizados en el sector occidental de la Cuenca Austral, durante las campañas 1964-65 y 1965-66. Inedit report of Yacimientos Petroliferos Fiscales (YPF).

Bowman, V.C., J.E. Francis, R.A. Askin, J.B. Riding \& G.T. Swindles. 2014. Latest Cretaceous-earliest Paleogene vegetation and climate change at the high southern latitudes: palynological evidence from Seymour Island, Antarctic Peninsula. Palaeogeography, Palaeoclimatology, Palaeoecology 408: 26-47.

Cantrill D.J. \& I. Poole. 2005. Taxonomic turnover and abundance in Cretaceous to Tertiary wood floras of Antarctica: implications for changes in forest ecology. Palaeogeography, Palaeoclimatology, Palaeoecology 215(3-4): 205-219.

Dettmann, M. E. \& M.R.A. Thomson. 1987. Cretaceous palynomorphs from the James Ross Island area, Antarctica-a pilot study. British Antarctic Survey Bulletin 77: 13-59.

Dolding, P.J. 1992. Palynology of the Marambio Group (Upper Cretaceous) of northern Humps Island. Antarctic Science 4(3): 311-326.

Friis E.M., P.R. Crane \& K.R. Pedersen. 2011. Early flowers and angiosperm evolution. Cambridge University Press.

Hammer, Ø., D.A.T. Harper \& P.D. Ryan. 2001. Paleontological statistics software: package for education and data analysis. Palaeontologia Electronica (4): 1-9.

Heywood, V.H., R.K. Brummitt, A. Culham \& O. Seberg. 2007. Flowering plant families of the world. Firefly Books Ltd., 424 pp.

Kraemer, P.E. \& A.C. Riccardi. 1997. Estratigrafía de la region comprendida entre los lagos Argentino y Viedma (49 $\left.49^{\prime}-50^{\circ} 10^{\prime} \mathrm{LS}\right)$, Provincia de Santa Cruz. Revista de la Asociación Geológica Argentina 52: 333-360.

Lupia R, S. Lidgard \& P.R. Crane. 1999. Comparing palynological abundance and diversity: implications for biotic replacement during the Cretaceous angiosperm radiation. Paleobiology 25: 305-340.

Macellari, C.E., C.A. Barrio \& M.J. Manassero. 1989. Upper Cretaceous to Paleocene depositional sequences and sandstone petrography of southwestern Patagonia (Argentina and Chile). Journal of South American Earth Science 2(3): 223-239.

Martínez, L.C., S. Archangelsky, M. B. Prámparo, \& 
A. Archangelsky. 2016. Early Cretaceous palm pollen tetrads from Patagonia, Argentina. Cretaceous Research 59: 129-139.

Moyano Paz, D., C. Tettamanti, A.N. Varela, A. Cereceda \& D.G. Poiré. 2018. Depositional processes and stratigraphic evolution of the Campanian deltaic system of La Anita Formation, Austral-Magallanes Basin, Patagonia, Argentina. Latin American Journal of Sedimentology and Basin Analysis 25(2): 69-92.

Nagalingum N.S., A.N. Drinnan, R. Lupia, S. McLoughlin. 2002. Fern spore diversity and abundance in Australia during the Cretaceous. Review of Palaeobotany and Palynology 119: 69-92.

Novas, F., F. Agnolin, S. Rozadilla, A. AranciagaRolando, F. Brissón-Eli, M. Motta, et al. 2019. Paleontological discoveries in the Chorrillo Formation (upper Campanian-lower Maastrichtian, Upper Cretaceous), Santa Cruz Province, Patagonia, Argentina. Revista del Museo Argentino de Ciencias Naturales nueva serie 21(2):217-293.

Papú, O.H. 1988a. Estudio palinológico de la Formación Paso del Sapo (Cretácico Superior) en la localidad de "Los Fortines", valle medio del Río Chubut. Parte 1: Esporas triletes Laevigati y Apiculati. $4^{\circ}$ Congreso Argentino de Paleontología y Bioestratigrafía, Actas 3: 63-73.

Papú, O.H. 1988b. Estudio palinológico de la Formación Paso del Sapo (Cretácico Superior) en la localidad de "Los Fortines", valle medio del Río Chubut. Parte 2: Esporas triletes Murornati, Tricrassati y esporas monoletes. $4^{\circ}$ Congreso Argentino de Paleontología y Bioestratigrafía, Actas 3: 75-85.

Papú, O.H. 1989. Estudio palinológico de la Formación Paso del Sapo (Cretácico superior), valle medio del Río Chubut. Granos de polen, consideraciones estadísticas, paleoecológicas y paleoambientales. Ameghiniana 25(3): 193-202.

Papú, O.H. 2002. Nueva microflora de edad Maastrichtiana en la localidad de Calmu-Co, sur de Mendoza, Argentina. Ameghiniana 39: 415-426.

Papú, O.H. \& E.G. Sepúlveda. 1995. Datos palinológicos de la Formación Los Alamitos en la localidad de Montoniló, departamento 25 de Mayo, Río Negro, Argentina. Sus relaciones con unidades colindantes coetáneas. $6^{\circ}$ Congreso Argentino de Paleontología y Bioestratigrafía (Trelew), Actas: 195-200.

Povilauskas, L. 2010. Palinología del entorno CretácicoPaleógeno de SW de la Provincia de Santa Cruz. Significado estratigráfico y paleoambiental. Ph.D. thesis (unpublished), Universidad Nacional de La Plata, Argentina.

Povilauskas, L. 2011. Palinología de la Formación Monte Chico (Cretácico tardío) de la Provincia de Santa Cruz, Argentina: Esporas. Revista Brasileira de Paleontologia 14: 255-268.

Povilauskas, L. 2012. Palinología de la Formación Monte Chico (Cretácico Tardío) de la Provincia de Santa Cruz, Argentina: granos de polen de gimnospermas. Revista Brasileira de Paleontología 15(1): 85-94.

Povilauskas, L. 2013. Palinología de angiospermas de la Formación Monte Chico (Cretácico Superior) de la Provincia de Santa Cruz, Argentina. Revista Brasileira de Paleontología 16(1): 115-126.

Povilauskas, L. 2016. Estudio palinológico de la Formación Cerro Cazador (Cretácico Tardío) de la Provincia de Santa Cruz, Argentina. Revista Brasileira de Paleontologia 19(1): 71-84.

Povilauskas, L., V. Barreda \& S. Marenssi. 2008. Pollen and spores of the La Irene Formation (Maastrichtian), Southwestern Santa Cruz Province: First results. Geobios 41: 819-831.

Riccardi, A.C. 1983. Informe paleontológico de los perfiles Estancia Alta Vista, Arroyo El Turbio. Inedit report of Yacimientos Petroliferos Fiscales (YPF).

Riccardi, A.C. \& E.O. Rolleri. 1980. Cordillera Patagónica Austral. In: J.C.M. Turner (Ed.), Segundo Simposio de Geología Regional Argentina. Academia Nacional de Ciencias, Córdoba, vol. 2: 1173-1304.

Sickmann, Z.T., T.M. Schwartz \& S.A. Graham. 2018. Refining stratigraphy and tectonic history using detrital zircon maximum depositional age: an example from the Cerro Fortaleza Formation, Austral Basin, southern Patagonia. Basin Research 30(4): 708-729.

Sickmann, Z.T., T.M. Schwartz, M.A. Malkowski, S.C. Dobbs \& S.A. Graham. 2019. Interpreting large detrital geochronology data sets in retroarc foreland basins: An example from the Magallanes-Austral Basin, southernmost Patagonia. Lithosphere 11(5): 620-642.

Tettamanti, C., D. Moyano Paz, A.N. Varela, D.E. Tineo, L.E. Gómez-Peral, D.G. Poiré, A. Cereceda \& A.L. Odino Barreto. 2018. Sedimentology and fluvial styles of the Uppermost Cretaceous Continental Deposits of the Austral-Magallanes Basin, Patagonia, Argentina. Latin American Journal of Sedimentology and Basin Analysis 25(2): 149-168.

Tryon, A.F. \& B. Lugardon. 2012. Spores of the Pteridophyta: surface, wall structure, and diversity based on electron microscope studies. Springer Science \& Business Media, New York, 648 pp.

Vallati, P. 2010. Asociaciones palinológicas con angiospermas en el Cretácico Superior de la Cuenca Neuquina, Argentina. Revista Brasileira de Paleontologia 13(2): 143-158.

van Geel, B. 1976. Fossil spores of Zygnemataceae in ditches of a pre-historic settlement in Hoogkarspel (The Netherlands). Review of Palaeobotany and Palynology 22(4): 337-344.

Volkheimer, W., L. Scafati \& D.L. Melendi. 2007. Palynology of a Danian warm climate wetland in central northern Patagonia, Argentina. Revista Española de Micropaleontología 39(1-2): 117-134.

Doi: 10.22179/REVMACN.22.664

Recibido: 14-XI-2019 Aceptado: 9-IV-2020 